\title{
Manual Treatment of Urban Wastewater by Chemical Precipitation for Production of Hydroponic Nutrient Solutions
}

\author{
Tânia Correia ${ }^{1 *}$, Mariana Regato ${ }^{1}$, Adelaide Almeida ${ }^{1,2}$, Teresa Santos' ${ }^{1}$ \\ Leonor Amaral', Fátima Carvalho ${ }^{1,2}$ \\ 1 Polytechnic Institute of Beja, Street Pedro Soares - IPB Campus, 7800-295 Beja, Portugal \\ 2 FibEnTech - Fiber Materials and Environmental Technologies, Street Marques de Avila e Bolama, 6201-001, \\ Covilhã, Portugal \\ ${ }^{3}$ CENSE - Center for Environmental and Sustainability Research, NOVA School of Science and Technology, \\ NOVA University Lisbon, Caparica, Portugal \\ * Corresponding author e-mail: tania.correia@ipbeja.com
}

\begin{abstract}
An urban wastewater treatment system was developed in Portugal for posterior in situ feasibility testing at the Bulgarian Antarctic Base, using its domestic wastewater. The aim of this system was to develop a low cost, integrated approach for wastewater treatment and production of nutrient solutions (NS) for hydroponic cultivation of lettuce (Lactuca sativa var. crispa) in Antarctic stations, or any other place where the lack of resources and logistical hardships make the wastewater treatment and reuse impractical. The wastewater treatment system consisted in manual agitation lime chemical precipitation (LCPm) and effluent natural neutralization (NN) by atmospheric $\mathrm{CO}_{2}$ carbonation reactions (with and without air injection). The resulting effluent/NS had macronutrient values (nitrogen and phosphorous) for the hydroponic cultivation of lettuce below the values of commercial NS and a high $\mathrm{pH}(\mathrm{pH} \approx 8)$. The treatment achieved a total coliform removal rate of $100 \%$. Before the LCPm treatment system development, several lime-based reagents were tested under different reaction $\mathrm{pH}$ and using mechanical agitation, to access their organic matter removal efficiency, as chemical oxygen demand (COD). The best COD removal results obtained were: commercial $\mathrm{Ca}(\mathrm{OH})_{2}(\mathrm{pH} 11.5-89 \%)$, reagent grade $\mathrm{Ca}(\mathrm{OH})_{2}(\mathrm{pH} 11.5-79 \%)$ and $\mathrm{CaO}(\mathrm{pH} 12.0-64 \%)$.
\end{abstract}

Keywords: urban wastewater, antarctica, chemical precipitation, $\mathrm{CO}_{2}$ capture, hydroponics

\section{INTRODUCTION}

Wastewater recycling and reuse is aligned with the UN Sustainable Development Goals (SDGs), Goal 6, as it becomes a more pressing issue due to the water scarcity and the need for improving sanitation. The agricultural application of urban wastewater as a source of nutrients and water has been extensively used and is currently practiced in almost all arid/semiarid regions of the world (Magwaza et al., 2020). Nevertheless, the long-term use of wastewater in crop irrigation comes with environmental impacts (groundwater and soil contamination) and may cause soil structure degradation, which leads to the crop productivity decrease (Prazeres et al., 2017). Hydroponic cultivation systems are an alternative biological technology for the agricultural reuse of wastewater and nutrient recovery without the environmental consequences of traditional methods (Prazeres et al., 2017). The hydroponic cultivation systems are widely used in commercial crop production and consist in cultivating plants, without the use of soil, with the roots submerged in a liquid nutrient solution. Due to their high levels of nutrients, urban wastewaters are a low-cost option to provide nutrients for the food crop production in hydroponic cultivating systems. Approximately $20 \%$ of the manufactured nitrogen and phosphorous in the world is contained in domestic wastewaters and due to urban concentration, the majority is recoverable (Puyol et al., 2017). Therefore, 
the urban wastewater treatment has the potential to be an important part of circular economy if the resources (nutrients and the water itself) are efficiently recovered and/or reused.

On the other hand, the application of chemical precipitation processes in wastewater treatment, besides being an alternative to the classical biological systems, represents a viable option for decentralized treatment, because they have lower space requirements, are more amenable to automatic control and can be designed to provide useful by-products (Semerjian et al., 2003). Chemical precipitation has long been used as a pre-treatment for the improvement of subsequent biological treatments, in which the hydroponic cultivation techniques can be included. When applied to urban wastewater and cheese production wastewater, high-pH chemical precipitation (lime based) has shown efficient removals of: microorganisms $(60-100 \%), \mathrm{BOD}_{5}$, biochemical oxygen demand, (64-75\%), COD, chemical oxygen demand (57-72\%), TSS, total suspended solids (75-91\%) and TP, total phosphorous (71-93\%), temporary hardness and high molecular weight organic compounds (humic and fulvic acids) (Carvalho et al., 2012; Prazeres et al., 2016; Semerjian et al., 2003). However, the lime chemical precipitation processes require a $\mathrm{pH}$ neutralization step. The use of atmospheric $\mathrm{CO}_{2}$ to neutralize the effluent coming from the lime precipitation is an economical technology that produces a byproduct (precipitate) rich in organic matter and nutrients and could also lead to the mitigation of greenhouse gases (Lim et al., 2010; Prazeres et al., 2016). Despite its possible advantages, high hydraulic retention times have been obtained and wastewater carbonation has been poorly studied (Lim et al., 2010; Prazeres et al., 2016).

Expeditioners have been bringing plants to Antarctica since the early days of exploration, more than 46 plant production facilities have operated in the continent and 9 hydroponic facilities are currently in operation (since the implementation of the Protocol on Environmental Protection to the Antarctic Treaty or Madrid Protocol, the importation of non-sterile soil is to be avoided to the maximum extent practicable, which leaves the hydroponic cultivation techniques as the only viable option for the in-situ food production) (Bamsey et al., 2015, 2016). The expeditioners' need for association with plants is both based on the practical need for fresh food and rooted in psychological factors, as research shows that the presence of plants can be helpful to the expeditioners' mental health (Bamsey et al., 2015, 2016). Therefore, maintaining the human presence in Antarctica implies a complex logistic involving food transport but also the water and waste management. Antarctica poses several challenges to the operation of conventional wastewater treatment facilities (biological systems) as the climate (cold and dry) imposes heavy energy requirements (for heating and equipment operation), which are usually provided by burning fossil fuels (Stark et al., 2015, 2016). The wastewater treatment systems must cope with high load fluctuation because of the seasonal variation in the wastewater volume (there is high variation in winter and summer population at the Stations) (Stark et al., 2015, 2016). The Madrid Protocol states that precautions should be taken to prevent the introduction of non-native microorganisms to Antarctica, although it does not specifically mention the risks posed by wastewater. Nonetheless, the Antarctic wastewater contains high levels of human enteric pathogens and non-native microbes that can survive in coastal Antarctic waters and lead to the introduction of non-native microbes as well as genetic pollution when not properly eliminated (Allinson et al., 2018; Stark et al., 2015, 2016). The wastewater generated at Antarctic stations has comparable characteristics to urban wastewater (a mix of human, domestic and light industrial liquid waste); however, it is more concentrated due to the water supply limitations and the absence of stormwater runoff (Stark et al., 2015, 2016). Given the inherent characteristics of the lime chemical precipitation processes in wastewater treatment, as stated above, we think they may be a viable alternative for improving the wastewater treatment and reuse in Antarctica and can help reduce the human footprint of Antarctic stations, given the relevance of hydroponic cultivation for the in-situ food production.

\section{MATERIAL AND METHODS}

\section{Urban wastewater collection}

In Portugal, the raw urban wastewater was collected from the wastewater treatment plant in the village of Vidigueira (approximately 5932 inhabitants) in October 2018. The raw wastewater was stored in $6 \mathrm{~L}$ capacity PET containers at $4{ }^{\circ} \mathrm{C}$ 
for characterization. Thereafter, the raw wastewater was frozen at $-20{ }^{\circ} \mathrm{C}$ until use.

The main characteristics of these urban wastewaters are a mean chemical oxygen demand (COD) of $1358 \mathrm{mg} \cdot \mathrm{L}^{-1}$, mean biological oxygen demand after 5 days $\left(\mathrm{BOD}_{5}\right)$ of $483 \mathrm{mg} \cdot \mathrm{L}^{-1}$ and mean $\mathrm{pH}$ of 7.03. Table 1 summarizes the rest of the parameters analyzed. Table 1 indicates that total suspended solids (TSS), COD, BOD , total nitrogen (TN) and total phosphorous (TP) are above typical values, both for the Portuguese and for North American urban wastewaters (Monte et al., 2010, 2016). Total alkalinity is within the typical values found in the literature, between 62.1 and $367.0 \mathrm{mg} \cdot \mathrm{L}^{-1}$ (Prazeres et al., 2017). The urban wastewater of Vidigueira (UWV) can then be considered a wastewater with a high organic and nutrient load (Monte et al., 2010, 2016). However, the $\mathrm{BOD}_{5} / \mathrm{COD}$ ratio $(0.36)$ is low, $<0.4$, so the UWV are theoretically poorly biodegradable (Nagwekar, 2014).

\section{Lime chemical precipitation (LCP) tests}

Using $200 \mathrm{~mL}$ of urban wastewater, in $250 \mathrm{ml}$ capacity glass beakers, different lime-based reagents (at a concentration of $200 \mathrm{~g} \cdot \mathrm{L}^{-1}$ ) were tested: commercial $\mathrm{Ca}(\mathrm{OH})_{2}$ or hydrated lime; reagent grade $\mathrm{Ca}(\mathrm{OH})_{2}$ and $\mathrm{CaO}$ or quick lime. The reagents were added drop by drop, under vigorous mechanical stirring (magnetically agitated, rotation speed of $300 \mathrm{rpm}$ ), stirring was maintained until different precipitation $\mathrm{pH}$ were reached, from 9.5 to 12.5 . After stirring, the effluent was left to settle for 120 minutes. Then, the sludge volume and physicochemical characteristics of the pre-treated wastewater (supernatant) were analyzed (section Analytical methods).

\section{Manual agitation lime chemical precipitation (LCPm) test}

For the LCPm, a volume of $5 \mathrm{~L}$ of urban wastewater was vigorously agitated for 1 minute, in the PET reactors, after the addition of a predetermined dose of hydrated lime, to a $\mathrm{pH}$ of 11.5. The effluent was settled for 120 minutes before starting the atmospheric $\mathrm{CO}_{2}$ carbonation for natural $\mathrm{pH}$ neutralization.

\section{Natural neutralization (NN) test}

The urban wastewater for the $\mathrm{NN}$ tests was pre-treated manually. The NN tests consisted in keeping $4 \mathrm{~L}$ of the manually pre-treated urban wastewater, with the settled sludge, in an open recipient, at room temperature, to allow for the reaction with the atmospheric $\mathrm{CO}_{2}$. Two sets of experiments were conducted: the NN process was

Table 1. Raw UWV characterisation

\begin{tabular}{|c|c|c|}
\hline Parameters & Units & Mean \pm SD \\
\hline $\mathrm{pH}$ & Sorensen & $7.03 \pm 0.29$ \\
\hline Conductivity & $\mathrm{mS} \cdot \mathrm{cm}^{-1}$ & $1.358 \pm 0.105$ \\
\hline Turbidity & NTU & $196 \pm 30$ \\
\hline TSS & $\mathrm{mg} \cdot \mathrm{L}^{-1}$ & $295 \pm 49$ \\
\hline COD & $\mathrm{mg} \cdot \mathrm{O}_{2} \cdot \mathrm{L}^{-1}$ & $1344 \pm 23$ \\
\hline $\mathrm{BOD}_{5}$ & $\mathrm{mg} \cdot \mathrm{O}_{2} \cdot \mathrm{L}^{-1}$ & $483 \pm 75$ \\
\hline $\mathrm{BOD}_{5} / \mathrm{COD}$ & - & 0.36 \\
\hline TP & $\mathrm{mg} \cdot \mathrm{P} \cdot \mathrm{L}^{-1}$ & $13.5 \pm 1.9$ \\
\hline Nitrate & $\mathrm{mg} \mathrm{N}-\mathrm{NO}_{3} \cdot \mathrm{L}^{-1}$ & $0.5 \pm 0.1$ \\
\hline Nitrite $^{(1)}$ & $\mathrm{mg} \mathrm{N}^{-\mathrm{NO}_{2}}-\mathrm{L}^{-1}$ & - \\
\hline $\mathrm{NH}_{4}+$ & $\mathrm{mg} \mathrm{N} \mathrm{NH}_{4}^{+} \cdot \mathrm{L}^{-1}$ & $70.5 \pm 6.5$ \\
\hline N-Kjeldahl & $\mathrm{mg} \mathrm{N} \cdot \mathrm{L}^{-1}$ & $148.1 \pm 10.2$ \\
\hline N-Organic & $\mathrm{mg} \mathrm{N} \cdot \mathrm{L}^{-1}$ & $77.5 \pm 13.9$ \\
\hline TN & $\mathrm{mg} \mathrm{N} \cdot \mathrm{L}^{-1}$ & $150.8 \pm 10.5$ \\
\hline Total alkalinity & $\mathrm{mg} \mathrm{CaCO}_{3} \cdot \mathrm{L}^{-1}$ & $300.8 \pm 8.6$ \\
\hline Phenolphthalein alkalinity & $\mathrm{mg} \mathrm{CaCO}{ }_{3} \cdot \mathrm{L}^{-1}$ & $0.0 \pm 0.0$ \\
\hline Total hardness & $\mathrm{mg} \mathrm{CaCO}{ }_{3} \cdot \mathrm{L}^{-1}$ & $202.9 \pm 9.5$ \\
\hline Calcium & $\mathrm{mg} \mathrm{Ca}^{2+} \cdot \mathrm{L}^{-1}$ & $65.6 \pm 4.1$ \\
\hline Magnesium & $\mathrm{mg} \mathrm{Mg}^{2+} \cdot \mathrm{L}^{-1}$ & $9.4 \pm 4.1$ \\
\hline Total coliforms & UFC/100 ml & $>542$ \\
\hline
\end{tabular}

(1) Bellow detection limit. 
tested with and without air injection, see Figure 1. The $\mathrm{pH}$ and EC measurements were taken daily, and the experiment was maintained until the supernatant $\mathrm{pH}$ was close to 8 . Each test was conducted in triplicate. At the end of the experiment the physicochemical characteristics of the pretreated wastewater (supernatant) were analyzed (section Analytical methods).

\section{Analytical methods}

The raw and treated urban wastewaters were characterized by the following parameters: $\mathrm{pH}$ was measured with a WTW InoLab apparatus. Electrical conductivity (EC) was measured with a Jenway 4510 meter. Chemical oxygen demand (COD) was determined with an Ultrospec 2000 spectrophotometer, according to the standard dichromate closed reflux method (Baird et al., 2017). Biological oxygen demand (BOD) was determined with the respirometric method (Baird et al., 2017). Nitrate was determined by means of the sodium salicylate method (Rodier et al., 2009). Nitrites were determined with the colorimetric method (Baird et al., 2017). Ammonium nitrogen was determined with the distillation method in a BUCHI Distillation Unit B-316 and then by titration (Baird et al., 2017). Kjeldahl nitrogen was determined by means of the MacroKjeldahl method (Baird et al., 2017). The calcium and magnesium determinations were made by titration with EDTA using eriochrome black $\mathrm{T}($ calcium + magnesium) and calcon (calcium) indicators (Baird et al., 2017). Phenolphthalein and total alkalinity were determined by titration (Baird et al., 2017). The total coliforms were determined according to internal document of the Microbiological Analysis Laboratory of the Department of Technologies and Applied Sciences of IBeja (n. d.).

\section{Statistical analysis}

All samples were analyzed in triplicate. Descriptive statistics were performed in Microsoft Excel (version 1905). The graphs were drawn using GraphPad Prism version 5.0 for Windows and in Microsoft Excel (version 1905).

\section{RESULTS AND DISCUSSION}

\section{Lime chemical precipitation (LCP)}

Lime chemical precipitation (LCP) is a process that leads to the formation of an instantaneous and intense precipitate followed by a vigorous "sweeping" phenomenon of particles (Semerjian et al., 2003). The process is explained by the reactions that take place when lime is added to the wastewater (Prazeres et al., 2016). These reactions lead to the formation of insoluble species, such as calcium carbonate Eq. (1-4), magnesium carbonate, and magnesium hydroxide Eq. (3-4), and phosphates Eq. (5-6):

$$
\begin{aligned}
& \mathrm{Ca}(\mathrm{OH})_{2}+\mathrm{H}_{2} \mathrm{CO}_{3} \rightleftarrows \mathrm{CaCO}_{3} \downarrow+2 \mathrm{H}_{2} \mathrm{O} \\
& \mathrm{Ca}(\mathrm{OH})_{2}+\mathrm{Ca}\left(\mathrm{HCO}_{3}\right)_{2} \rightleftarrows 2 \mathrm{CaCO}_{3} \downarrow+2 \mathrm{H}_{2} \mathrm{O}
\end{aligned}
$$

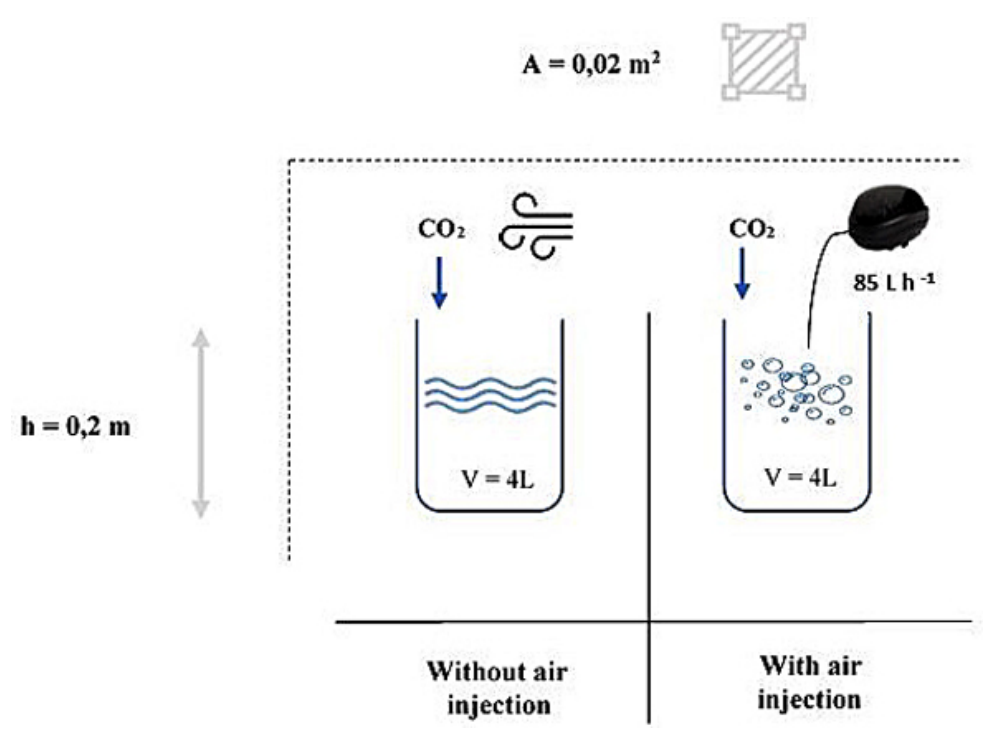

Figure 1. Atmospheric $\mathrm{CO}_{2}$ carbonation $(\mathrm{NN})$ test experimental design. Each test (with and without air injection) was performed in triplicate. For each reservoir, the water height was $0.2 \mathrm{~m}$, superficial area was $0.02 \mathrm{~m}^{2}$ and water volume $4 \mathrm{~L}$. For the test with the injection of air the pump flow rate was $85 \mathrm{~L} \mathrm{~h}^{-1}$ 


$$
\begin{aligned}
& \mathrm{Ca}(\mathrm{OH})_{2}+\mathrm{Mg}\left(\mathrm{HCO}_{3}\right)_{2} \rightleftarrows \mathrm{MgCO}_{3} \downarrow+ \\
& \mathrm{CaCO}_{3} \downarrow+2 \mathrm{H}_{2} \mathrm{O} \\
& \mathrm{Ca}(\mathrm{OH})_{2}+\mathrm{MgCO}_{3} \rightleftarrows \mathrm{Mg}(\mathrm{OH})_{2} \downarrow+\mathrm{CaCO}_{3} \downarrow \\
& 3 \mathrm{Ca}(\mathrm{OH})_{2}+2 \mathrm{PO}_{4}^{3-} \rightleftarrows \mathrm{Ca}_{3}\left(\mathrm{PO}_{4}\right)_{2} \downarrow+6 \mathrm{OH}^{-} \\
& 4 \mathrm{Ca}(\mathrm{OH})_{2}+3 \mathrm{PO}_{4}^{3-}+\mathrm{H}_{2} \mathrm{O} \rightleftarrows \mathrm{Ca}_{4} \mathrm{H}_{\left(\mathrm{PO}_{4}\right)_{3} \downarrow} \\
& +9 \mathrm{OH}^{-}
\end{aligned}
$$

Figure 2 describes the effect of the reaction $\mathrm{pH}$ on lime dose and sludge formation. The lime doses added ( 0.4 to $\left.1.6 \mathrm{~g} \mathrm{~L}^{-1}\right)$ increased the $\mathrm{pH}$ from 9.5 to 12.5 due to the addition of $\mathrm{OH}^{-}$to the solution (Renou et al., 2009). The highest $\mathrm{pH}$ value reached was 12.5 and no further increase in $\mathrm{pH}$ was observed with the lime added, since lime is poorly soluble and added in excess to the stoichiometric values, for these experimental purposes, it will contribute to sludge but also be dissociated in calcium cations $\left(\mathrm{Ca}^{2+}\right)$ and hydroxide anions $\left(\mathrm{OH}^{-}\right)$, increasing the concentration of these ions in the solution. When the solution becomes saturated, which happens above $\mathrm{pH}$ 12.0, the solubility of the lime decreases, and calcium tends to remain constant in the solution (Renou et al., 2009).

Overall, the lowest reagent consumption was obtained with hydrated lime, as opposed to quick lime that consumes the highest amounts of reagent (except for $\mathrm{pH}$ 12.5), see Figure 2. Moreover, quick lime and reagent grade calcium hydroxide produced consistently larger amounts of sludge than hydrated lime. The lowest sludge production was obtained for hydrated lime at $\mathrm{pH} 11.0$ (3.8\% of the wastewater volume) as opposed to quicklime at $\mathrm{pH} 12.0(11.5 \%$ of the wastewater volume).
During the treatment, EC reaches the minimum values at $\mathrm{pH} 11.5\left(0.899 \mathrm{mS} \mathrm{cm}^{-1}, 1.031 \mathrm{mS}\right.$ $\mathrm{cm}^{-1}$ and $1.043 \mathrm{mS} \mathrm{cm}^{-1}$ for hydrated lime, reagent grade calcium hydroxide and quicklime, respectively), see Figure 3. After pH 12.0, EC quickly starts to rise, due to the saturation of the solution, as mentioned above. The EC reduction is due to the chemical precipitation of organic and inorganic (e.g. calcium and magnesium) salts in the form of hydroxides or carbonates, Eq. (1-4).

Figure 4 shows the variation of COD during LCP. The removal of organic matter is related to the addition of lime in excess and its subsequent drag during sedimentation (Prazeres et al., 2016; Renou et al., 2009; Semerjian et al., 2003). When appreciable amounts of lime are added, the calcium hydroxide and calcium carbonate produced act as coagulating agents and improve the drag of the organic matter, as mentioned above, and the "sweeping effect" occurs. Other contaminants (metals, oils and fats and other organic substances) also become prone to the drag from the solution, helped by the produced precipitate and sedimentation in the mantle occurs, which results in a clarified supernatant (without a flocculation step). Overall, the most effective reagent in COD removal was hydrated lime ( $75 \%$ to $89 \%$ removals) and the least effective quicklime ( $44 \%$ to $64 \%$ removals). The maximum COD removal was obtained at a reaction $\mathrm{pH}$ of 11.5 using hydrated lime, see Figure 4.

The optimal reagent for LCP was determined to be hydrated lime at a dose of $0.7 \mathrm{~g} \mathrm{~L}^{-1}$ (reaction $\mathrm{pH}$ of 11.5) for the tested conditions and characteristics of the urban wastewater used. This dose was selected based on the supernatant quality (COD removal and final EC) and the volume of the produced sludge associated with the reagent needs. This dose removes $89 \%$ of COD, see Figure 4 .

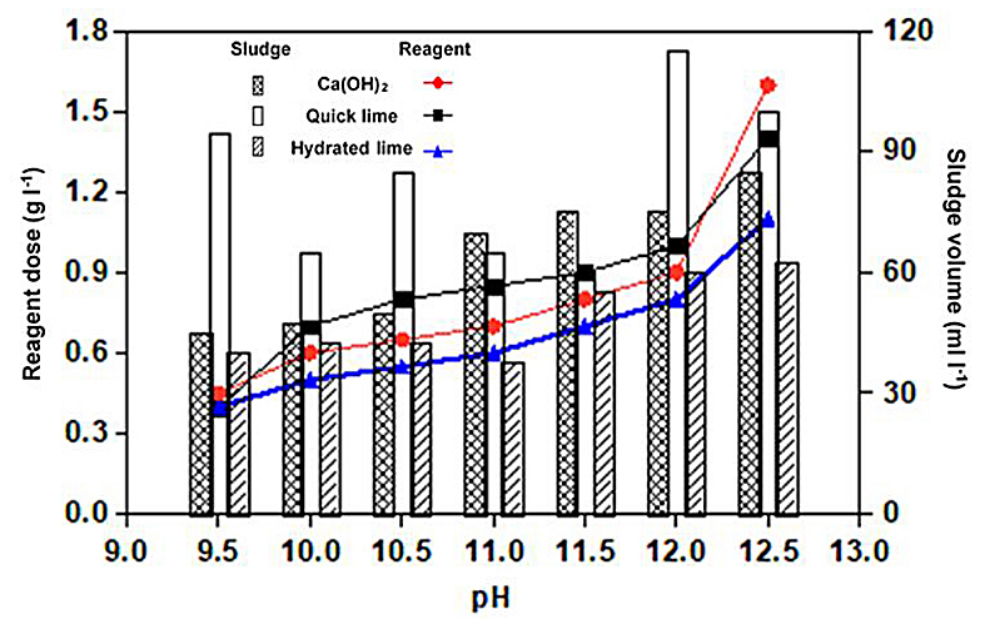

Figure 2. Effect of the reaction $\mathrm{pH}$ on lime dose and sludge formation 


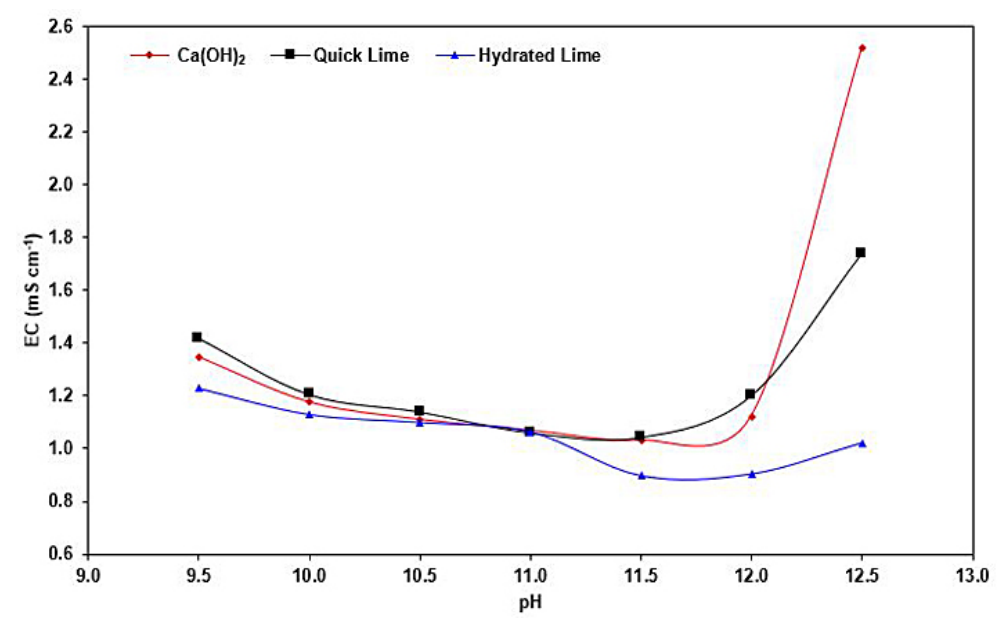

Figure 3. Effect of the reaction $\mathrm{pH}$ on $\mathrm{EC}\left(\mathrm{mS} \mathrm{cm}^{-1}\right)$ during LCP

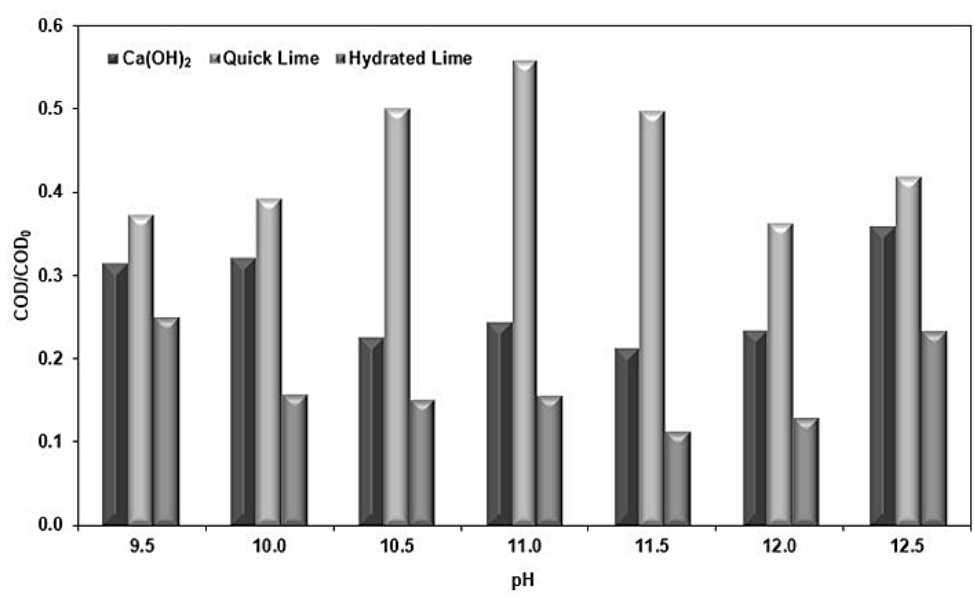

Figure 4. Effect of the reaction $\mathrm{pH}$ on COD removal $\left(\mathrm{COD}_{0}=1344 \mathrm{mg} \mathrm{O}_{2} \mathrm{~L}^{-1}\right)$ during LCP

\section{Natural neutralization (NN)}

Figure 5 demonstrates the decrease in $\mathrm{pH}$ during the atmospheric $\mathrm{CO}_{2}$ carbonation in the presence of the UWV sludge (between 0 to 4/9 days, with and without air injection, respectively). A consistent drop in $\mathrm{pH}$ is observed to a $\mathrm{pH}$ range considered acceptable, but not ideal, for hydroponic cultivation of lettuce $(\mathrm{pH} \approx 8)$. The $\mathrm{pH}$ value is an important parameter due to nutrient bioavailability in the nutrient solution (Asao, 2012). The observed decrease in $\mathrm{pH}$ over time is justified by the following reactions.

$$
\begin{aligned}
& \mathrm{CO}_{2}(\mathrm{~g}) \rightleftarrows \mathrm{CO}_{2}(\mathrm{aq}) \\
& \mathrm{CO}_{2}(\mathrm{aq})+\mathrm{H}_{2} \mathrm{O}(\mathrm{l}) \rightleftarrows \mathrm{H}_{2} \mathrm{CO}_{3}(\mathrm{aq}) \\
& \mathrm{H}_{2} \mathrm{CO}_{3} \rightleftarrows \mathrm{H}^{+}+\mathrm{HCO}_{3}^{-} \\
& \mathrm{HCO}_{3}^{-} \rightleftarrows \mathrm{H}^{+}+\mathrm{CO}_{3}^{2-}
\end{aligned}
$$

The carbonic acid consumption from the UWV during the LCPm process to produce calcium carbonate, Eq. (1), causes a chemical disequilibrium of $\mathrm{CO}_{2}$ between the effluent and the atmosphere. In order to counteract this, disequilibrium atmospheric $\mathrm{CO}_{2}$ dissolves in water through the liquid-air interface until equilibrium is reached, Eq. (7). Carbonic acid, Eq. (8), is formed and decomposes naturally into molecules of bicarbonate, Eq. (9) and carbonate, Eq. (10), producing hydrogen ions $\left(\mathrm{H}^{+}\right)$and leading to a $\mathrm{pH}$ decrease.

An EC increase from the $2^{\text {nd }}$ day onwards is observed both for the effluent with and without air injection. The EC increases from 0.994 to $1.042 \mathrm{mS} \mathrm{cm}^{-1}$ and from 1.037 to $1.168 \mathrm{mS} \mathrm{cm}^{-1}$, for the effluent without air injection and for the effluent with air injection, respectively, Figure 5. This increase may be related with evaporation phenomena and redissolution of ions (responsible by EC) from sludge to the supernatant. 
a)

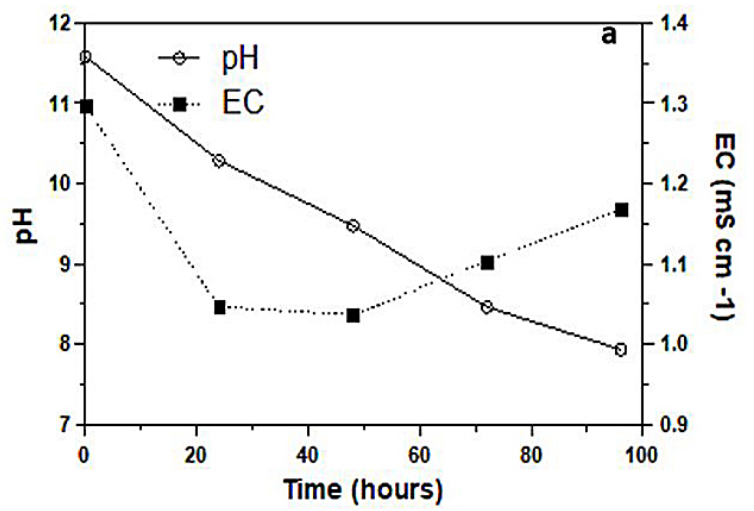

b)

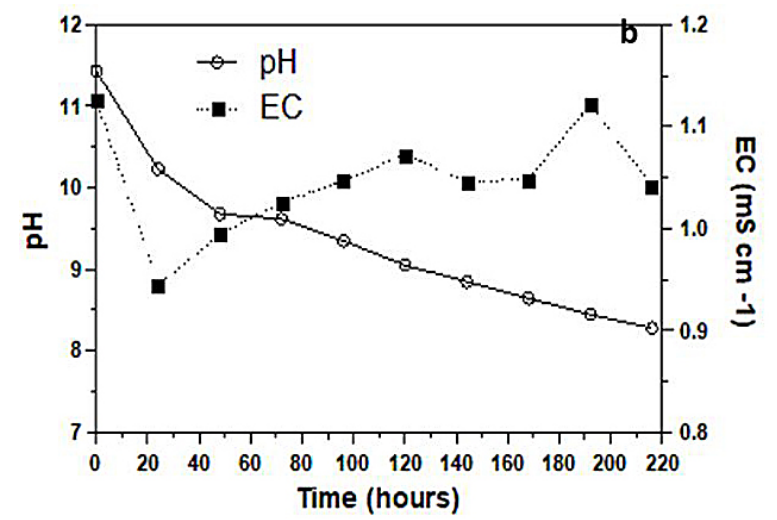

Figure 5. pH neutralization and EC evolution during the NN tests:

(a) With air injection $\left(851 \mathrm{~h}^{-1}\right)$. (b) Without air injection

\section{LCPm and NN effluent quality and NS production}

In order to produce treated wastewater based on nutrient solutions for the hydroponic cultivation of lettuce, the lime chemical precipitation process was performed with manual agitation (LCPm) and the effluent $\mathrm{pH}$ natural neutralization performed with the injection of air. The manual agitation and need for a faster neutral neutralization were determined by the need to replicate the conditions (lack of specialized equipment and time constraints) to be found during in-situ feasibility testing at the Bulgarian Antarctic Base.

The reaction parameters used in the LCPm, were based on the optimum parameters determined in the LCP tests, a dose of $0.7 \mathrm{~g} \mathrm{l}^{-1}$ of hydrated lime was applied to the UWV in a single dose but agitation was performed manually, as described in materials and methods. The NN of the effluent was performed with the injection of air, $\left(85 \mathrm{l} \mathrm{h}^{-1}\right)$ and, as in the previous $\mathrm{NN}$ tests; a $\mathrm{pH}$ of $\approx 8$ was obtained after 4 days of treatment $\left(\mathrm{pH}_{0} \approx 11.5\right)$.

The contaminant removal efficiency of the $\mathrm{LCPm}$ and NN treatment process in the UWV, Figure 6, was of $98 \%$ for Turbidity, $92 \%$ for TSS, $88 \%$ for COD, $85 \%$ for BOD5, $89 \%$ for TP, $38 \%$ for $\mathrm{N}^{-\mathrm{NH}_{4}+}, 58 \%$ for $\mathrm{N}-\mathrm{Kjeldahl}, 75 \%$ for $\mathrm{N}$-Organic, $58 \%$ for $\mathrm{TN}$, and $100 \%$ for total coliforms. In the final effluent, there was also a significant increase in calcium (93\%) and total hardness $(40 \%)$, which was not shown in the results. The reason for the observed increase in calcium and total hardness is most likely due to the fact that because the hydrated lime dose applied was, stoichiometric, too high for the bicarbonate in the solution, even for the lowest dose of lime applied, some $\mathrm{Ca}^{2+}$ cations remain in the effluent, as explained in the previous paragraph, LCP tests. The removal values for $\mathrm{N}-\mathrm{NO}_{2}{ }_{2}^{-}$and $\mathrm{N}-\mathrm{NO}_{3}{ }^{-}$are not represented, since they were either negligible or below the detection limits.

The effluent from the LCPm and NN treatment process applied to the UWV reached the Portuguese legal parameters for irrigation reuse (Decree-Law nr 119/2019, $21^{\text {st }}$ of August). TP was reduced to $1.4 \mathrm{mg} \mathrm{P} \mathrm{L}^{-1}\left(<5 \mathrm{mg} \mathrm{P} \mathrm{L}^{-1}\right)$, turbidity was reduced to $3.7 \mathrm{NTU}(\leq 5 \mathrm{NTU})$ and total coliforms were reduced to $0.7 \mathrm{CFU} / 100 \mathrm{~mL}$ (E.coli, $\leq 10 \mathrm{CFU} / 100 \mathrm{~mL}$ ). As E. coli constitutes a subgroup of total coliform bacteria and there was a reduction of total coliforms by $100 \%$, the elimination of the subgroup E. coli was not tested. The most relevant limiting factor for irrigation reuse, according to the Portuguese legislation, is the $\mathrm{BOD}_{5}\left(67 \mathrm{mg} \mathrm{O}_{2} \mathrm{~L}^{-1}\right)$ which is $40 \%$ above the maximum legal value $\left(\leq 40 \mathrm{mg} \mathrm{O}_{2} \mathrm{~L}^{-1}\right)$ for wastewater reuse with several restrictions. The nitrogen values $\mathrm{TN}\left(63.1 \mathrm{mg} \mathrm{L}^{-1}\right)$ and $\mathrm{N}^{-\mathrm{NH}_{4}}{ }^{+}$ (43.2 $\mathrm{mg} \mathrm{L}^{-1}$ ) which are also above the legislated values $\left(15 \mathrm{mg} \mathrm{N} \mathrm{L}^{-1}\right.$ and $\left.10 \mathrm{mg} \mathrm{NH}_{4}^{+} \mathrm{L}^{-1}\right)$, are facultative. In the final effluent, TSS $\left(24 \mathrm{mg} \mathrm{L}^{-1}\right)$ is also above the most restrictive values, for wastewater reuse without restrictions $\left(\leq 10 \mathrm{mg} \mathrm{L}^{-1}\right)$ but are under the maximum legal values for more restricted uses $\left(\leq 35 \mathrm{mg} \mathrm{L}^{-1}\right)$.

However, for NS destined to lettuce cultivation in hydroponic system, the opposite is the case, as most values are below optimum (TN, TP, $\mathrm{Ca}^{2+}$ and $\mathrm{Mg}^{2+}$ ), see Table 2, except $\mathrm{pH}$ which, as discussed before is high (effluent $\mathrm{pH}$ after $\mathrm{NN}$ is 8.4, the ideal $\mathrm{pH}$ should be 5.6-6.0), and EC (effluent $\mathrm{EC}$ is $1.144 \mathrm{mS} \mathrm{cm}^{-1}$, the ideal EC should be $1.600 \mathrm{mS} \mathrm{cm}^{-1}$ ), Table 2. The hydroponic 


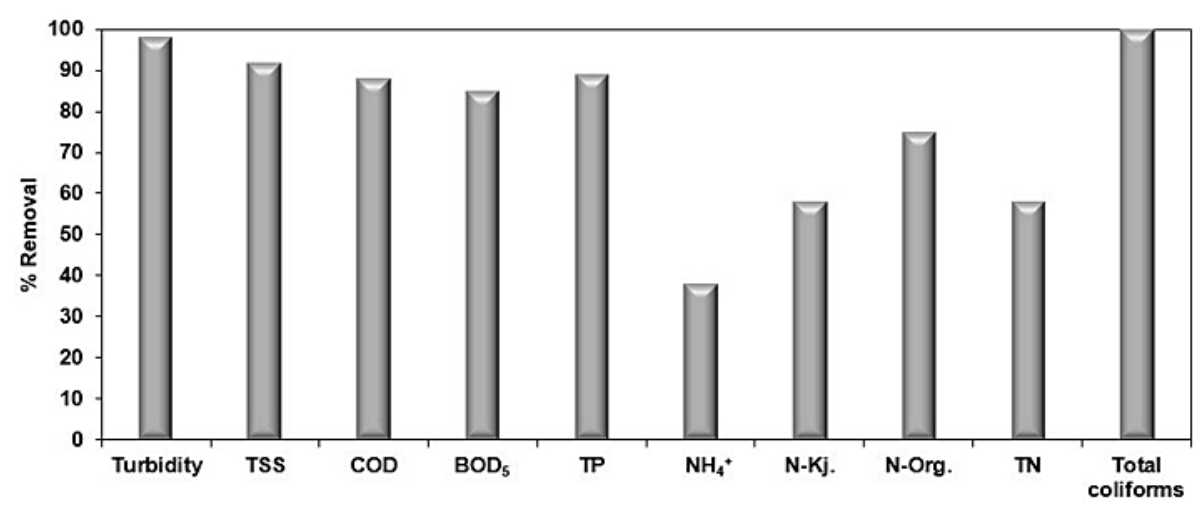

Figure 6. Contaminant removal the UWV after the LCPm and NN treatment

systems using domestic wastewater (both treated with biological methods and untreated) as nutrient solution for the cultivation of lettuce have been investigated before, (Eregno et al., 2017; Keller et al., 2005; Lihua et al., 2002). Keller et al. (Keller et al., 2005), successfully cultivated lettuce using secondary effluent as NS with biomass production results "similar and better than the other treatments" and Lihua et al. (Lihua et al., 2002) obtained positive lettuce biomass results, but lower than using commercial NS, cultivating lettuce with septic tank effluents as NS. In both cases (Keller et al., 2005; Lihua et al., 2002), the NS derived from the domestic wastewater was not ideal (mostly because of low $\mathrm{N}$ and $\mathrm{P}$ values) but successfully supported the experimental hydroponic cultivation of the lettuce plants; therefore, the NS obtained from the LCPm and NN treatment of the UWV has the potential for reuse, especially since it poses a low risk of pathogen contamination because of the elimination of total coliforms.

\section{CONCLUSIONS}

This integrated pre-treatment that combines manual agitation lime precipitation (LCPm) with atmospheric $\mathrm{CO}_{2}$ carbonation $(\mathrm{NN})$ in the presence of the sludge is proposed to treat low biodegradability and high organic matter/nutrient wastewaters to obtain an effluent which can be used as a nutrient solution for the hydroponic cultivation of lettuce (Lactuca sativa var. crispa). The proposed sequence is a low-cost treatment solution, since lime is an inexpensive product widely used in industry and wastewater treatment, and $\mathrm{NN}$ does not need chemical addition or specialized maintenance. Additionally, the manual agitation allows it to be performed where the energy supply and specialized equipment are not readily available.

From this work, the following conclusions can be drawn:

- The LCP reagent with the highest removal efficiency of organic matter, as COD, is hydrated lime, on all $\mathrm{pHs}$ analyzed.

- The LCP reaction $\mathrm{pH}$ that allowed the highest removal efficiencies of organic matter, as COD, was 11.5 for most reagents tested (except for $\mathrm{CaO}$, for which the highest efficiency was at $\mathrm{pH}$ 12.0).

- The hydrated lime dose applied to the LCPm was $0.7 \mathrm{~g} \mathrm{~L}^{-1}$ (reaction $\mathrm{pH}$ of 11.5) and removals of COD, $88 \%, \mathrm{BOD}_{5}, 86 \%$, TP, $89 \%$, $\mathrm{N}$-organic, $75 \%$ and total coliform count, $100 \%$ were achieved matching the values found in literature for mechanical agitation processes.

Table 2. Composition of nutrient solution made according to Huett's lettuce formulation (ideal for lettuce cultivation in hydroponic systems) and composition of the nutrient solution obtained from the LCPm and NN treated UWV wastewater. The nutrient values represented are only the ones analyzed for this work

\begin{tabular}{|l|c|c|c|c|c|c|}
\hline \multicolumn{1}{|c|}{ Parameters } & $\mathrm{pH}$ & $\mathrm{EC}$ & $\mathrm{TN}$ & \multicolumn{1}{c|}{$\mathrm{TP}$} & $\mathrm{Ca}^{2+}$ & $\mathrm{Mg}^{2+}$ \\
\hline Units & $\mathrm{pH}$ & $\mathrm{mS} \mathrm{cm}{ }^{-1}$ & \multicolumn{4}{|c|}{$\mathrm{mg} \mathrm{L}^{-1}$} \\
\hline $\begin{array}{l}\text { Huett's lettuce formulation } \\
\text { (Parks et al., 2011) }\end{array}$ & $\begin{array}{c}5.6-6.0 \\
\text { (Brechner et al., 2013) }\end{array}$ & 1.600 & 116 & 22 & 70 & 20 \\
\hline Treated UWV & 8.4 & 1.144 & 63.1 & 1.4 & 50.6 & 8.4 \\
\hline
\end{tabular}


- The NN process, with air injection, decreased $\mathrm{pH}$ to an acceptable value of $\approx 8$, over only 4 days, faster than without air injection.

- According to national legislation quality was not achieved for reuse in irrigation since $\mathrm{CBO}_{5}$ was too high ( $>40 \mathrm{mg} \mathrm{O}_{2} \mathrm{~L}^{-1}$ ).

- The final effluent characteristics are not optimum for a hydroponic NS (because of the elevated $\mathrm{pH}$ and low nutrient values), but the fact that total coliforms were eliminated indicates a possible decrease in pathogen load, that shows its viability for this purpose.

\section{Acknowledgements}

Publication is funded by the Polish National Agency for Academic Exchange under the International Academic Partnerships Programme from the project „Organization of the 9th International Scientific and Technical Conference entitled Environmental Engineering, Photogrammetry, Geoinformatics - Modern Technologies and Development Perspectives".

Project with financial support of FCT, I.P./MCTES through national funds (PIDDAC) and the Portuguese Polar Program (PROPOLAR).

\section{REFERENCES}

1. Allinson, M., Kadokami, K., Shiraishi, F., Nakajima, D., Zhang, J., Knight, A., ... Allinson, G. 2018. Wastewater recycling in Antarctica: Performance assessment of an advanced water treatment plant in removing trace organic chemicals. Journal of Environmental Management, 224(January), 122-129. https://doi.org/10.1016/j.jenvman.2018.07.020.

2. Asao, T. 2012. Hydroponics - a standard methodology for plant biological research. (T. Asao, Ed.) (1st ed.). Rijeka: InTech.

3. Baird, R.B., Eaton, A.D., \& Rice, E.W. (Eds.). 2017. Standard Methods for the Examination of Water and Wastewater (23 rd, Vol. 1). Washington: American Public Health Association. American Water Works Association. Water Environment Federation.

4. Bamsey, M.T., Zabel, P., Zeidler, C., Gyimesi, D., Schubert, D., Kohlberg, E., ... Graham, T. 2015. Review of Antarctic Greenhouses and Plant Production Facilities: A Historical Account of Food Plants on the Ice. In 45th International Conference on Environmental Systems (pp. 1-36).

5. Bamsey, M.T., Zabel, P., Zeidler, C., Vrakking, V., \& Schubert, D. 2016. Early Trade-offs and Top-Level Design Drivers for Antarctic Greenhouses and Plant
Production Facilities. In 46 th International Conference on Environmental Systems (pp. 1-20).

6. Carvalho, M.D.F.N.De, Prazeres, A.R.D.S., \& Toledo, F.J.R. 2012. Tratamento de águas residuais da indústria de queijo mediante processos em série de precipitação química, neutralização natural e biodegradação aeróbia. Portugal: INPI.

7. Eregno, F.E., Moges, M.E., \& Heistad, A. 2017. Treated greywater reuse for hydroponic lettuce production in a green wall system: Quantitative health risk assessment. Water (Switzerland), 9(7). https:// doi.org/10.3390/w9070454.

8. Lihua, C., Shiming, L., Xizhen, Z., \& Yinghu, L. 2002. Treatment and utilization of septic tank effluent using vertical flow constructed wetlands and hydroponic, 4-7.

9. Lim, M., Han, G.C., Ahn, J.W., \& You, K.S. 2010. Environmental remediation and conversion of carbon dioxide (CO2) into useful green products by accelerated carbonation technology. International Journal of Environmental Research and Public Health. https://doi.org/10.3390/ijerph7010203.

10. Magwaza, S.T., Magwaza, L.S., Odindo, A.O., \& Mditshwa, A. 2020. Hydroponic technology as decentralised system for domestic wastewater treatment and vegetable production in urban agriculture: A review. Science of the Total Environment, 698, 134154. https://doi.org/10.1016/j. scitotenv.2019.134154.

11. Ministros, P.D.C.DE. 2019. Decreto-Lei n.o 119/2019 de 21 de agosto. Diário Da República No159, I Série A., 21-44.

12. Monte, H.M., \& Albuquerque, A. 2010. Reutizacao de Águas Residuais. (ISEL \& ERSAR, Eds.) (1st ed.). Lisboa: ERSAR; ISEL.

13. Monte, H.M., Santos, M.T., Barreiros, A.M., \& Albuquerque, A. 2016. Tratamento de Águas Residuais Operações e Processos de Tratamento Físico e Químico. (E. ISEL, Ed.) (1st ed.). Lisboa: ERSAR; ISEL.

14. Nagwekar, P. R. 2014. Removal of Organic Matter from Wastewater by Activated Sludge Process - Review. International Journal of Science, Engineering and Technology Research, 3(5), 1260-1263.

15. Prazeres, A.R., Albuquerque, A., Luz, S., Jerónimo, E., \& Carvalho, F. 2017. Hydroponic System: A Promising Biotechnology for Food Production and Wastewater Treatment. In: A. Grumezescu \& A.-M. Holban (Eds.), Food Biosynthesis (1st ed.). Elservier, pp. 317-350.

16. Prazeres, A.R., Rivas, J., Paulo, Ú., Ruas, F., \& Carvalho, F. 2016. Sustainable treatment of different high-strength cheese whey wastewaters: an innovative approach for atmospheric $\mathrm{CO} 2$ mitigation and fertilizer production. Environmental Science and Pollution Research, 23(13), 13062-13075. https:// doi.org/10.1007/s11356-016-6429-3. 
17. Puyol, D., Batstone, D. J., Hülsen, T., Astals, S., Peces, M., \& Krömer, J. O. 2017. Resource Recovery from Wastewater by Biological Technologies: Opportunities, Challenges, and Prospects. Frontiers in Microbiology, 7(January), 1-23. https://doi. org/10.3389/fmicb.2016.02106.

18. Renou, S., Poulain, S., Givaudan, J. G., Sahut, C., \& Moulin, P. 2009. Lime treatment of stabilized leachates. Water Science \& Technology, 673-686. https://doi.org/10.2166/wst.2009.014.

19. Rodier, J., Legube, B., \& Merlet, N. 2009. L'analyse de l'eau (9 th). Paris: Dunod.

20. Science, W., Keller, R., Zandonade, E., \& Cassini, S.T. 2005. Hydroponic cultivation of lettuce (Lactuca sativa) using effluents from primary, secondary and tertiary + UV treatments Hydroponic cultivation of lettuce (Lactuca sativa) using effluents from primary, secondary and tertiary + UV treatments, (November 2014). https://doi. org/10.2166/ws.2005.0012.

21. Semerjian, L., \& Ayoub, G.M. 2003. High-pHmagnesium coagulation-flocculation in wastewater treatment. Advances in Environmental Research, 7(2), 389-403. https://doi.org/10.1016/ S1093-0191(02)00009-6.

22. Stark, J.S., Corbett, P.A., Dunshea, G., Johnstone, G., King, C., Mondon, J.A., ... Riddle, M. 2016. The environmental impact of sewage and wastewater outfalls in Antarctica: An example from Davis station, East Antarctica. Water Research, 105, 602614. https://doi.org/10.1016/j.watres.2016.09.026.

23. Stark, J.S., Smith, J., King, C.K., Lindsay, M., Stark, S., Palmer, A.S., ... Riddle, M. 2015. Physical, chemical, biological and ecotoxicological properties of wastewater discharged from Davis Station, Antarctica. Cold Regions Science and Technology, 113, 52-62. https://doi.org/10.1016/j. coldregions.2015.02.006. 